\title{
Epigenetic clocks may come out of rhythm-implications for the estimation of chronological age in forensic casework
}

\author{
Barbara Elisabeth Koop ${ }^{1} \cdot$ Alexandra Reckert ${ }^{1} \cdot$ Julia Becker $^{1} \cdot$ Yang Han $^{2} \cdot$ Wolfgang Wagner $^{2} \cdot$ Stefanie Ritz-Timme $^{1}$
}

Received: 24 January 2020 / Accepted: 8 July 2020 / Published online: 14 July 2020

(C) The Author(s) 2020

\begin{abstract}
There is a growing perception that DNA methylation may be influenced by exogenous and endogenous parameters. Knowledge of these factors is of great relevance for the interpretation of DNA-methylation data for the estimation of chronological age in forensic casework. We performed a literature review to identify parameters, which might be of relevance for the prediction of chronological age based on DNA methylation. The quality of age predictions might particularly be influenced by lifetime adversities (chronic stress, trauma/post-traumatic stress disorder (PTSD), violence, low socioeconomic status/education), cancer, obesity and related diseases, infectious diseases (especially HIV and Cytomegalovirus (CMV) infections), sex, ethnicity and exposure to toxins (alcohol, smoking, air pollution, pesticides). Such factors may alter the DNA methylation pattern and may explain the partly high deviations between epigenetic age and chronological age in single cases (despite of low mean absolute deviations) that can also be observed with "epigenetic clocks" comprising a high number of CpG sites. So far, only few publications dealing with forensic age estimation address these confounding factors. Future research should focus on the identification of further relevant confounding factors and the development of models that are "robust" against the influence of such biological factors by systematic investigations under targeted inclusion of diverse and defined cohorts.
\end{abstract}

Keywords Epigenetic clocks $\cdot$ Forensic age estimation $\cdot$ Chronological age $\cdot$ Confounding factors

\section{Introduction}

In a globalized world, age estimation is an increasingly important task in Forensic Medicine. Indications for age estimation may be the clarification of unclear or unknown ages in living young migrants without valid identity documents, the identification of unknown deceased or the identification of the donor of a blood trace. Any indication for age estimation in a forensic context requires the use of the most accurate methods as well as the knowledge of error sources and influencing factors [1].

The description of age dependent DNA methylation patterns ("epigenetic clocks") [2-5] opened up new possibilities

Barbara Elisabeth Koop

B_Koop@gmx.de

1 Institute of Legal Medicine, University Hospital Düsseldorf, 40225 Düsseldorf, Germany

2 Helmholtz-Institute for Biomedical Engineering, Stem Cell Biology and Cellular Engineering, RWTH Aachen Faculty of Medicine, Aachen, Germany for developing innovative methods for age estimation. Numerous groups have been working on the development and optimization of these methods, and several models for the estimation of chronological age based on DNA methylation have been established, all of which are based on different numbers and combinations of $\mathrm{CpG}$ sites (for review see [6]). One of the best known models was developed by Horvath [2] and includes $353 \mathrm{CpG}$ sites. This model is further referred to as "Horvath clock".

The terms "epigenetic clock", "epigenetic age" and "epigenetic age estimation" are used somewhat differently in different scientific contexts. Their use in this review is derived from its topic "forensic age estimation". The aim of forensic age estimation is the (as precise as possible) estimation of chronological age. Models for the estimation of chronological age based on DNA methylation ("epigenetic age estimation") reveal age estimates ("epigenetic ages") that may differ from the chronological age, since DNA methylation is influenced by numerous factors during the complex processes of biological ageing. At the same time, "epigenetic age" reflects biological age that may be more or less correlated with the chronological age. 
The primary aim of research in the field of forensic epigenetic age estimation is to improve the accuracy of age estimation - either of living persons, deceased persons, or in the analysis of blood traces. In living persons, samples providing enough DNA in good quality can be collected easily, whereas quantity and quality of DNA in postmortem cases and traces in crime scene investigations are often restricted [7]. Quantity and quality of available DNA are crucial for the number of CpGs that can be analysed, and for the choice of the analysis technology. Prediction models developed from the analysis of high-quality and highquantity DNA samples may not easily be transferred to case work with low-quality and low-quantity DNA from traces. Another problem in optimization of methods for epigenetic age estimation is the method-to-method-bias; model data produced with method A may not be suitable for predicting age from a case sample based on data produced with method B. Regarding this, it is important to understand that the methods used for epigenetic age predictions as well as the choice of relevant $\mathrm{CpG}$ sites, have major impact on the accuracy of epigenetic age estimation. We have recently demonstrated an alternative selection of $65 \mathrm{CpGs}$ for epigenetic age predictions with Illumina BeadChip arrays. Furthermore, we have compared different methods for targeted analysis of age-associated DNA methylation changes with pyrosequencing, droplet digital PCR, and bisulfite barcoded amplicon sequencing [8]. Thus, we are aware that the choice of methods and clocks needs to be critically evaluated for the specific application.

Further questions arise from the biological context, since complex biological processes may have a relevant influence on DNA methylation. Apart from considering the aspects named above, the interpretation of DNA methylation data for age estimation requires - knowledge of biological confounding factors that may be of relevance in a forensic setting. This review focusses on these biological confounding factors.

Forensic research is already aware of the influence of exogenous and endogenous factors on the estimation of chronological age by epigenetic age estimation models, and a few studies have already reported a relevant impact of selected factors as ethnic factors, physical exercise and diseases [9-12] (for details see below). Spolnicka et al. [11] rightly pointed out that "...studies aiming to identify all potential players influencing differences in DNA methylation at particular loci between individuals at the same chronological age are important ...for better accuracy of age prediction models. Exploration of this issue is important for age prediction reliability in routine forensic investigation".

There are a barely manageable number of clinical and basic science publications dealing with exogenous and endogenous factors affecting DNA methylation. This review gives an overview of potential influencing factors that may actually be relevant in forensic casework and is intended to contribute to the conception of future research on the development of "specialized clocks" [13] for forensic age estimation.

We selected publications that highlight confounding factors in epigenetic age estimation and may be relevant in forensic casework; because of their relevance in forensic practise, we focussed on buccal swabs, saliva and blood as sources of DNA. Although we included only studies with reasonable sample sizes (see Tables 1 and 2) and a study design that allowed the identification of confounding factors, we are aware that some of the effects cited below have not been conclusively proven yet. Moreover, most models cited in the following text and in Tables 1 and 2 primarily focus on a better understanding of biological contexts, of biological ageing, and on the biological effects of the investigated factors - and were not developed for the estimation of chronological age. Thus, an overestimation of the effects of the named confounding factors on models developed for the estimation of chronological age in a forensic context is possible. Despite these methodological limitations, the factors listed in Tables 1 and 2 should at least be discussed as potential confounding factors as long as the risk of influence cannot be excluded.

\section{Reported factors with effects on epigenetic age}

Parameters that were repeatedly shown to impact epigenetic age-predictions were particularly observed in the following categories: Lifetime adversities (chronic stress, trauma/ PTSD, exposure to violence, low socioeconomic status/education), cancer, obesity and related diseases, insomnia, exposure to toxins (alcohol, smoking, air pollution, pesticides), sex and ethnicity (Table 1). Other factors so far have only been described once (Table 2).

\section{Impact of lifetime adversities on epigenetic age}

The effects of adverse living conditions have been addressed by numerous publications. Cumulative lifetime stress results in an increased epigenetic age measured via Horvath clock [14]. This effect was especially pronounced in advanced age. Moreover, severe stress-related diseases (psychotraumata or post-traumatic stress disorder (PTSD)) may lead to increased epigenetic age estimation. Boks et al. [15] found increased epigenetic age estimates in 96 traumatized male soldiers based on the application of the Horvath clock. Wolf and colleagues [16-18] investigated the effects of childhood or lifetime trauma: Regarding the Horvath clock, they did not find effects of PTSD and childhood trauma on epigenetic age. This finding was supported by Mehta et al. [19]. In contrast, a correlation between increased epigenetic age estimation and childhood trauma as well as lifetime PTSD severity was evident with the Hannum clock. The data presented in a 


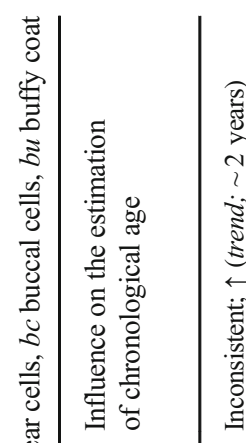

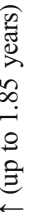

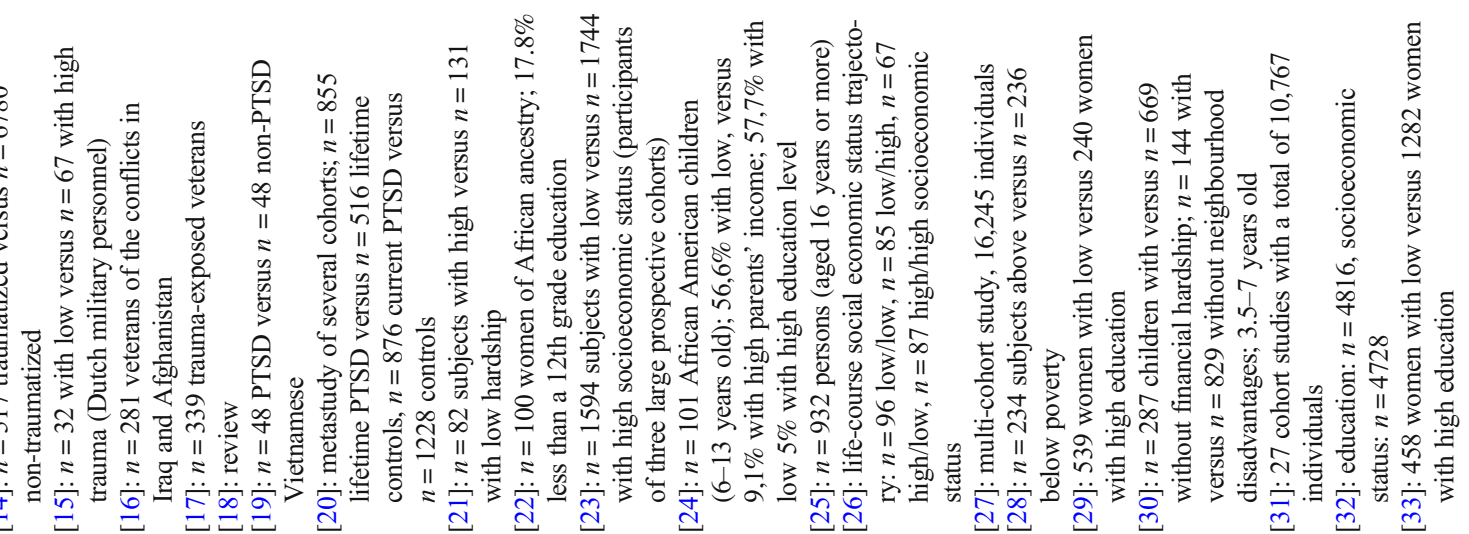

0
0

कि

ñ

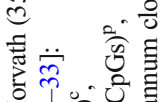

대에

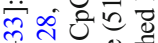

क於青

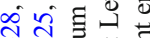

๙ิণ

$\dot{\vec{d}} \overrightarrow{\mathrm{d}}$ 这

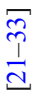

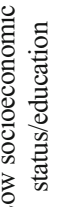




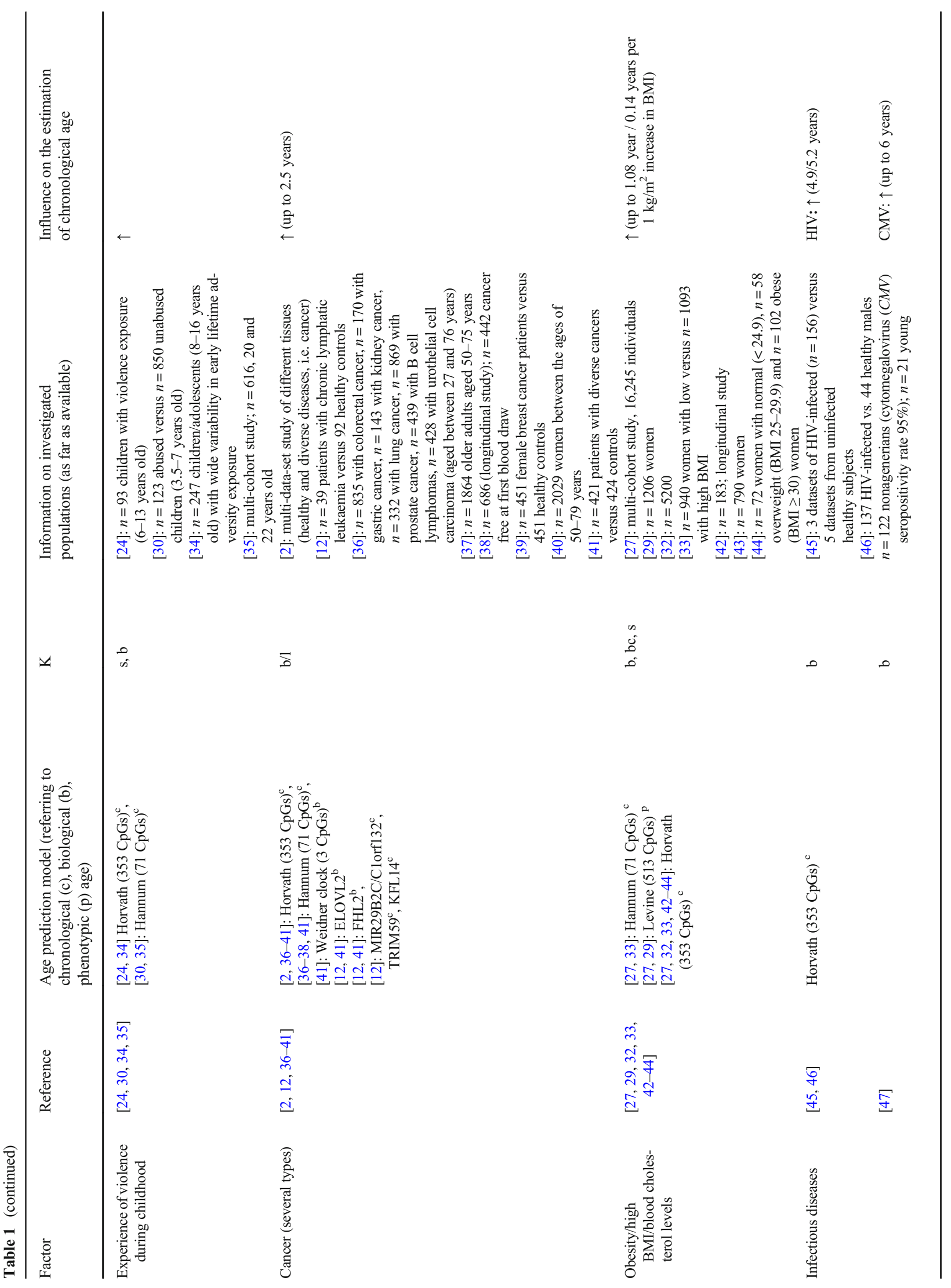




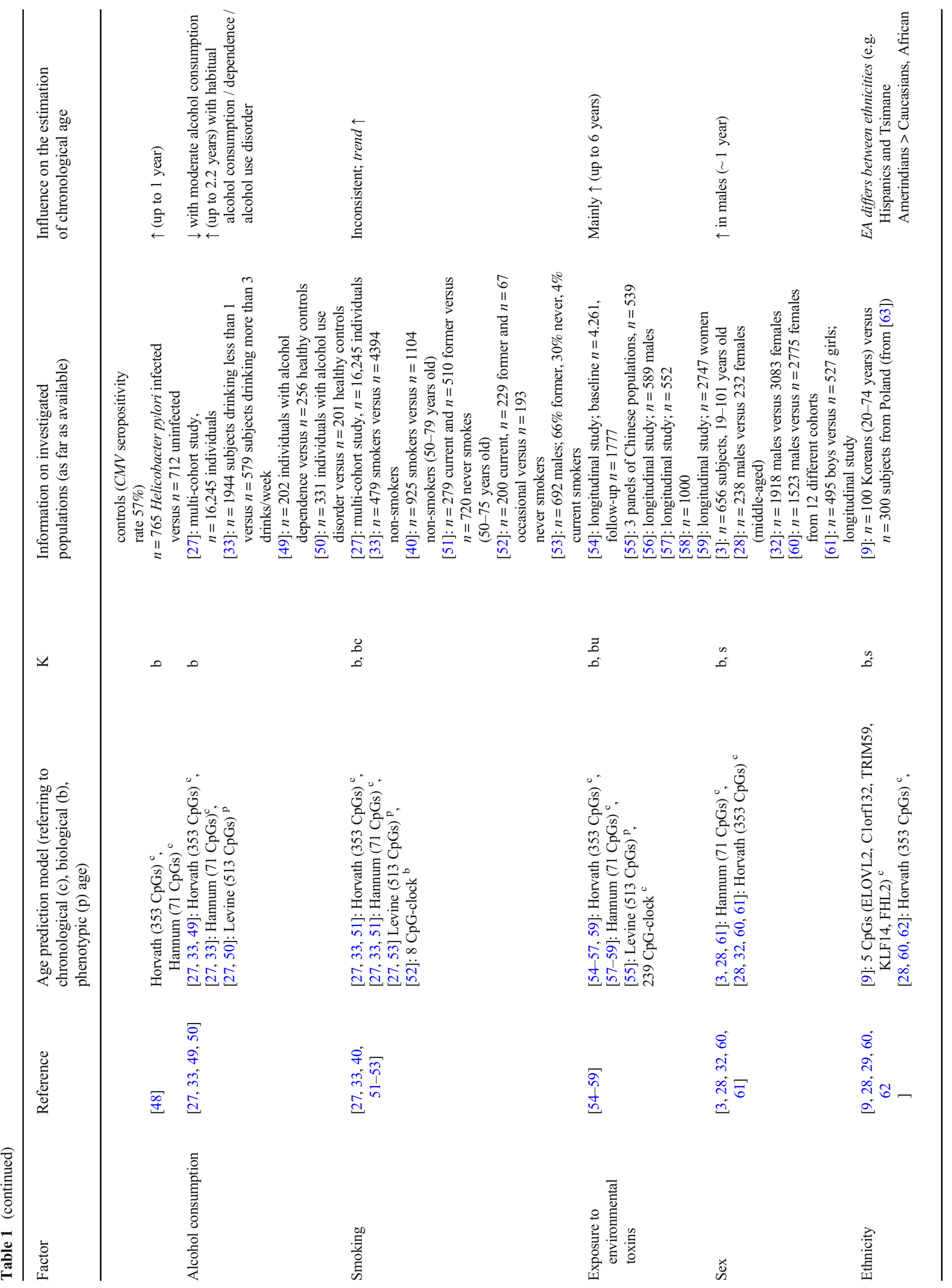




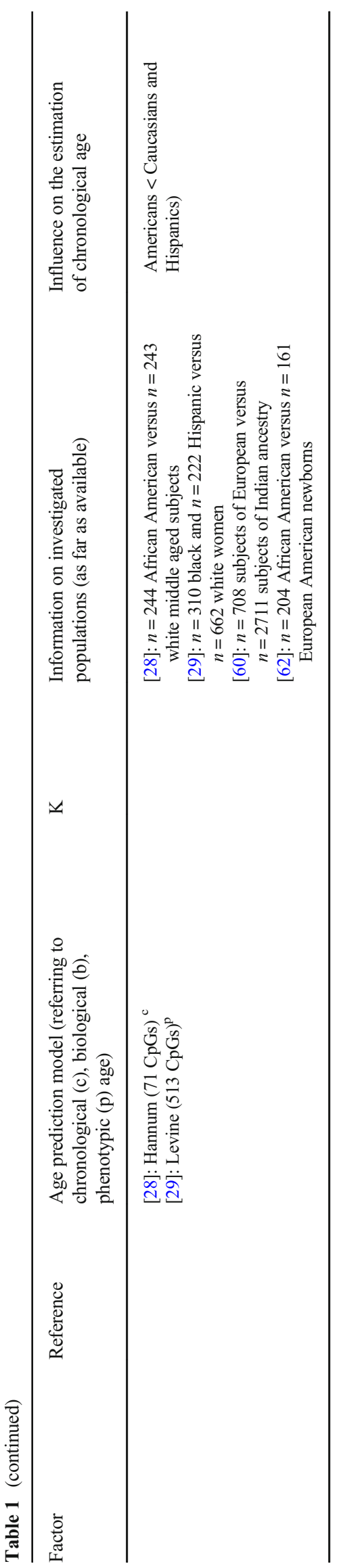

meta-analysis [20] hint to a higher impact of traumata experienced during childhood compared with those experienced in adulthood.

A low socioeconomic status and/or education level may also be associated with increased epigenetic age estimations. Chen et al. [21] investigated epigenetic ages of 379 African American adolescents in Georgia by analysing DNA from leukocytes. The epigenetic age of those individuals was increased by 1.42 years per measure of economic adversity. Another group [22] reported increased epigenetic age estimates in black middle-aged women with low income. They also investigated "the extent to which various health-related behaviours such as diet, exercise, smoking, alcohol consumption, and having health insurance could explain the effect of income on aging", but did not find "significant relationship between these variables and the speed to which aging occurred, and controlling for them had no impact on the association between income and biological aging." Fiorito et al. [23] described increased epigenetic age estimation in individuals with low socioeconomic status. The authors pointed out that this effect could be ameliorated by increasing socioeconomic status during life course; however, epigenetic age estimates still remained higher in those individuals compared with those with higher socioeconomic status. Jovanovic et al. [24] investigated DNA isolated from saliva of children and found an association between increased epigenetic age estimates and low socioeconomic status. These results are supported by the findings of Hughes et al. [25], who investigated the epigenetic age of individuals whose parents had been in semiskilled or unskilled occupations when the investigated individuals were 14 years old. At an age of 26 years, these individuals exhibited an increased epigenetic age of 1.07 years. In individuals without a working parent at an age of 14 years, this effect was even more severe, resulting in an increase of epigenetic age estimates of 1.85 years at an age of 26 years. The authors state that these "differences were not explained by smoking, adiposity or alcohol consumption, suggesting mechanisms independent of health behaviours are involved." These results are again supported by the data of Austin et al. [26], who reported an increase in epigenetic age in individuals with low early life socioeconomic status, as well as by Fiorito et al. [27], Tajuddin et al. [28], Thurston et al. [29] (regarding education) and Marini et al. [30] (regarding children), each of them with application of varying epigenetic clocks. Fiorito et al. [27] stated again that the increases of epigenetic age with low socioeconomic status were mainly independent of other lifestyle-related risk factors like smoking, obesity, alcohol intake, and low levels of physical activity. It is not clear yet, why a low socioeconomic status alters epigenetic age. Some groups assumed that this might be due to the stress of experiencing economic hardship, and that changes of DNA methylation are mediators of the association of low 


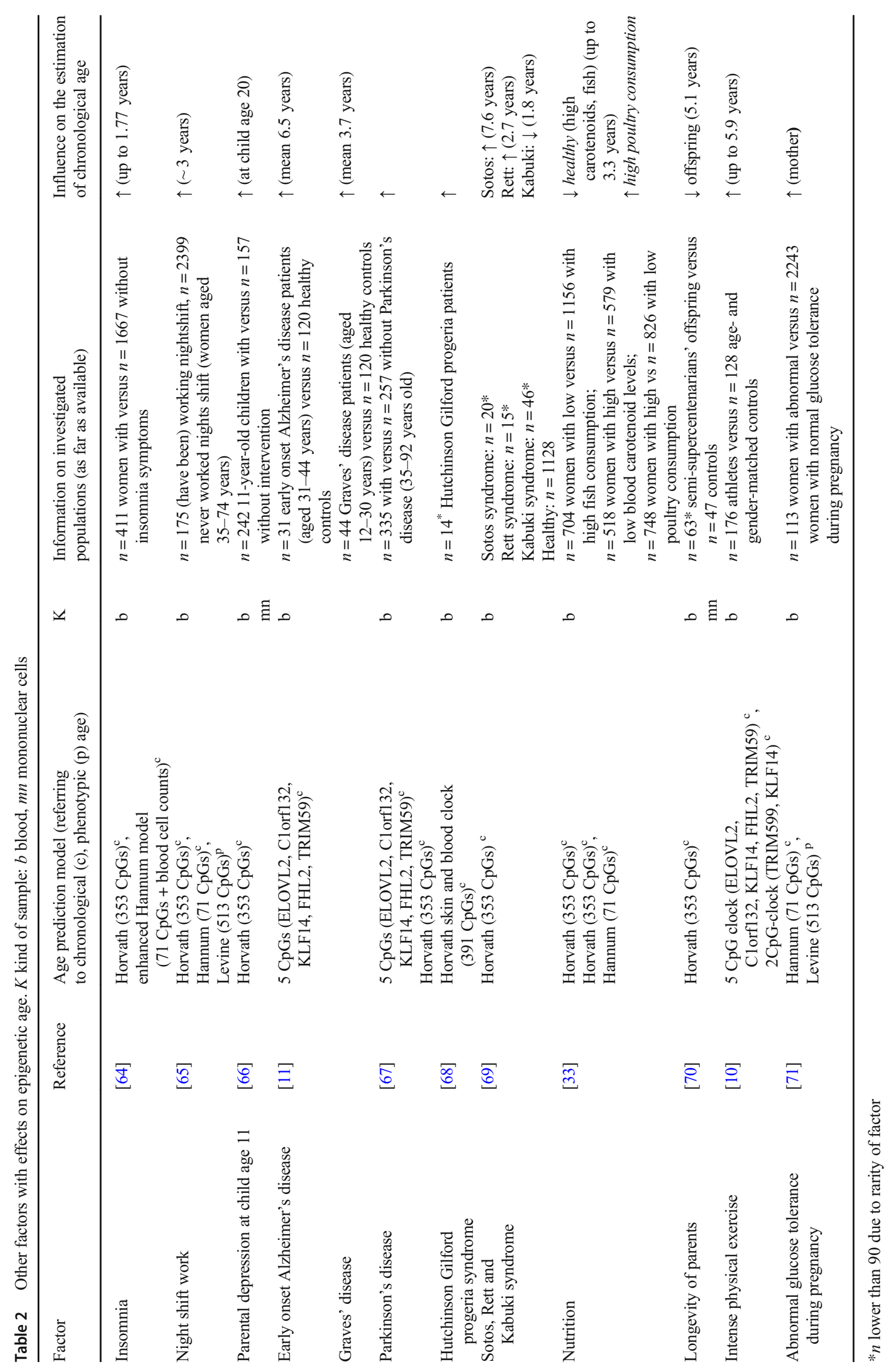


socioeconomic situation and a higher risk of diseases (e.g. cardiovascular diseases) [24, 26, 72, 73].

In contrast, high socioeconomic position or education levels have been shown to be associated with reduced epigenetic age estimates [31]. McCartney et al. [32] reported that each degree of increase in education level or socioeconomic status led to 0.05 years decrease of epigenetic age estimates. Additionally, Quach et al. [33] stated that higher education is associated with a decrease in epigenetic age estimates (4.14 years) and also described an inverse relationship between income and epigenetic age.

Exposure to violence was also suggested to impact epigenetic age. Based on the analysis of DNA isolated from saliva of children, Jovanovic et al. [24] reported an association between an increase of epigenetic age estimates and experiences of violence in a dose dependent manner. Similarly, Sumner et al. [34] found increased epigenetic age estimates and an advanced pubertal stage in children with threat-related early life adversity (e.g. violence). These results were supported by Marini at al. [30], who found "that exposure to abuse, financial hardship, or neighbourhood disadvantage during sensitive periods in early and middle childhood (...) (led to a) deviation of Hannum based epigenetic age from chronological age, even after considering the role of adversity accumulation and recency". Regarding Horvath clock, they did not find differences between estimated ages of children with or without exposure to violence. Brody et al. [35] described the effects of exposure to higher levels of racial discrimination on epigenetic age estimates and reported increased epigenetic age estimates in discriminated adolescents with less supportive families (known to ameliorate the effects of exposure to racial discrimination).

In forensic case work, age estimation in young migrants without valid identity documents has become highly relevant in these times of migration and flight [74]. In this context, the possible impact of adverse living conditions on epigenetic age estimation is of major importance. If an accumulation of stressors like experiences of violence and low socioeconomic status may cause increased epigenetic age estimates and, consequently, a false high age estimate, this may have serious consequences for the individual (e.g. legal responsibility).

\section{Epigenetic clocks may be distorted in non-infectious diseases}

Spolnicka et al. [11] tested an epigenetic model composed of five markers from five genes (ELOVL2, Clorf132, KLF14, FHL2 and TRIM59) for the estimation of chronological age in three disease groups (late and early onset Alzheimer's disease, Graves' disease). They reported aberrant hypermethylation and decreased prediction accuracy of chronological age for TRIM59 and KLF14 markers in the group of early onset Alzheimer's disease. In Graves' disease patients, an aberrant hypermethylation was observed for TRIM59, an aberrant hypomethylation for FHL2. In contrast, ELOVL2 and Clorf132 showed unchanged prediction accuracy in all disease groups. Analysis of the identical five markers in 39 blood samples from patients with chronic lymphocytic leukaemia (CLL) and 92 healthy individuals (control group) resulted in highly statistically differences between patients and controls for all CpGs, indicating a strong influence of CLL on agerelated methylation [12]. The authors concluded that "DNA methylation signature in blood does not predict calendar age in patients with chronic lymphocytic leukemia".

Altered DNA methylation patterns were not only observed in cancer which affects blood cell lines [12], but also in other common types of cancer like colorectal, gastric, kidney, lung, prostate and urothelial cancer [2, 36-41]. Dugue et al. [36] found that "epigenetic aging was associated with increased cancer risk, ranging from $4 \%$ to $9 \%$ per five-year age acceleration". Several other publications reported associations between cancer/cancer risk and an increase of epigenetic age estimates in blood of up to 2.5 years [37-41]. In fact, cancer is a monoclonal disease and hence the malignant cells capture the epigenetic makeup of the tumour initiating cell [75]. There is even evidence that for many types of cancer, the acceleration of epigenetic age is of prognostic value for disease development [76]. However, it is unknown so far if increased epigenetic age is a cause or consequence of cancer development. The aforementioned data are also of relevance for forensic casework: Blood samples of persons suffering from cancer may exhibit altered DNA-methylation levels that might result in false high age estimates. This may also be true if the cancer already exists, but is not diagnosed yet.

\section{Infectious diseases impact epigenetic age predictions}

Based on the DNA-methylation pattern in blood, epigenetic age of individuals infected with HIV was estimated 5.2 years higher compared with healthy controls [45]. These results were confirmed by Gross and colleagues [46]. Similarly, H. pylori and Cytomegalovirus (CMV) infections were associated with increased epigenetic age estimates $[47,48]$. In forensic casework, the impact of those infections on epigenetic age estimates has to be kept in mind, as they might result in deviations between estimated and chronological ages of up to 6 years. This point is of high importance regarding age estimation of unaccompanied young refugees without valid documents, as many refugees stem from African regions with high HIV-incidence, and additionally CMV infections are very common with up to $95 \%$ incidence in adults in many countries [77].

\section{Obesity fosters epigenetic ageing}

Obesity, high body mass index (BMI), and blood cholesterol have been shown to increase epigenetic age estimates. Nevalainen et al. [42] found increased epigenetic age 
estimates in middle-aged individuals with high BMI. These findings were supported by data of Simpkin et al. [43], McCartney et al. [32], Li et al. [44] and Thurston et al. [29]. Recently, Fiorito et al. [27] published data from a large multicohort study $(n=16,245)$, revealing increased epigenetic age estimates of up to 1.08 years $(p<0.001)$ for individuals with high BMI $(\mathrm{BMI} \geq 30)$. Individuals with lower BMI may exhibit low epigenetic ages [33].

\section{Alcohol, smoking, and environmental toxins affect epigenetic ageing}

Moderate alcohol consumption (1-7 drinks/week) was suggested to decrease epigenetic age [33]. In contrast, habitual alcohol consumption [27] and alcohol dependence [49] were associated with an increase in epigenetic age. These data were recently supported by Luo et al. [50].

There is clear evidence that smoking evokes specific DNA methylation changes [78]. The data available for the impact of smoking on epigenetic age estimations are still inconsistent. Some groups did not report any effects [33, 40, 51, 52]. Studies comprising larger sample sizes report increased epigenetic age estimates in smokers: McCartney et al. [32] investigated DNA from 5100 blood samples and found increased epigenetic age estimates in smokers. Fiorito et al. [27] investigated 16,245 blood samples and reported that smoking was associated with an increased epigenetic estimate of up to 1.57 years. Additionally, Yang et al. [53] reported that cumulative smoking (pack-years) was significantly associated with epigenetic acceleration.

Even exposure to environmental toxins has been shown to affect epigenetic age. Ward-Caviness et al. [54] reported an increase of epigenetic age with increased exposure to fine particulate matter and nitrogen oxide. Similarly, Li et al. [55] as well as Nwanaji-Enwerem et al. [56, 57] found increased epigenetic ages after exposure to black carbon or fine particulate matter. Lind et al. [58] described increased epigenetic age estimates in individuals exposed to pesticides. In contrast to this, White et al. [59] found a deceleration of the epigenetic age after exposure to $\mathrm{NO}_{2}$. However, the age acceleration effect of fine particulate matter varied from 2 to 6 years and depends on its composition.

\section{Epigenetic ageing is faster in men compared with women}

In age estimation models comprising of high numbers of markers, males are estimated older than females of identical age. This finding was first described by Hannum et al. [3], who found that - on the epigenetic level — men age approximately $4 \%$ faster than women. These results were supported by the findings of other studies based on different models for age estimation $[28,32,60,61]$. Notably, no difference in epigenetic age estimates between men and women were reported in one study based on a model comprising of only 8 CpGs [52].

\section{There may be differences in epigenetic ageing between ethnic groups}

Cho et al. [9] applied an epigenetic model for the estimation of chronological age (markers located in the ELOVL2, Clorf132, TRIM59, KLF14, and FHL2 genes) derived from a Polish population [63] to blood samples from 100 Koreans. They reported that the age predictive performance of the tested model was "relatively consistent across different population groups". However, at certain loci (FHL2, Clorf132, KLF14) the extent of the age association in Koreans was not identical to that of the Polish, and retraining of the models produced better prediction accuracy. Several other publications describe differences in epigenetic age estimates between same aged individuals of different ethnic groups, too [28, 29, 60, 62]. As an example, Hispanics and Tsimane Amerindians have been shown to exhibit accelerated epigenetic ageing compared with Caucasians, while African-Americans were suggested to have decelerated epigenetic ageing compared with Caucasians and Hispanics [60].

\section{Other factors with effects on epigenetic age}

Spolnicka [10] investigated the effects of intense physical exercise on DNA methylation and its impact on epigenetic estimation of chronological age: elite athletes exhibited accelerated DNA hypermethylation of TRIM59 and KLF14; both markers predicted the athletes to be several years older than controls (KLF14: on average 5.5 years older, TRIM59: on average 4.5 years older) [10].

Insomnia [64] and working night shift [65] were reported to increase epigenetic age estimates. Children experiencing a parent's depression at an age of 11 years exhibited increased epigenetic ages at an age of 20 years [66]. This effect could be ameliorated by psychosocial intervention for those children. Increased epigenetic age estimates have also been reported in patients suffering from age related diseases like Parkinson's disease [67]. Rare diseases like Hutchinson Gilford progeria, Sotos, Rett and Kabuki syndromes were also shown to affect epigenetic ages (up to +7.6 years (Sotos syndrome) $[68,69]$.

Other factors have been shown to decrease epigenetic age estimates, such as healthy nutrition (vegetables, fruit, fish) [33]. Additionally, Horvath et al. [70] reported an interesting association between epigenetic age estimates in individuals and longevity of their parents: children of 105-110-year-old parents were estimated significantly younger (however, this was only investigated in a small number of Italian individuals). The effects of physical 
activity on epigenetic age estimates seem to depend on the intensity of sports: elite athletes who exercised very intensely showed increased epigenetic age estimates [10], whereas leisure time physical activity did not affect epigenetic age estimates [79]. In contrast, samples from individuals with low physical activity (low score on International Physical Activity Questionnaire, LASA Physical Activity questionnaire, low Cambridge Physical Activity Index, sedentary job and no recreational activity or $<1 \mathrm{~h} /$ week of physical activity) showed a trend towards a slight increase in epigenetic age estimation [27]. Additionally, abnormal glucose tolerance during pregnancy has been shown to lead to increased epigenetic age estimates of mothers [71].

\section{Conclusions}

Epigenetics of ageing is an emerging field for forensic application, opening perspectives to estimate the chronological age of living persons, deceased persons, or of blood traces. The choice of relevant age-associated $\mathrm{CpGs}$ and of the method applied for DNA methylation analysis need to be adjusted to the specific needs. Targeted assays, e.g. by pyrosequencing, digital droplet PCR, or bisulfite barcoded sequencing, may provide cost-effective and robust alternatives to the frequently used Illumina BeadChip arrays [13, 80]. The development of prediction models should consider the reality of casework (e.g. high-quality and highquantity DNA samples versus low-quality and lowquantity DNA, e.g. from blood traces). Additionally, the method-to method-bias has to be addressed.

It becomes more and more evident that epigenetic ageing is influenced by diverse exogenous and endogenous factors. Knowledge of these factors and of their impact is highly relevant for epigenetic age estimation — in forensic casework as well as in research. This review summarizes factors that may be relevant in forensic context. Although not all of them have been conclusively proven yet, they should at least be regarded as potential confounding factors that may contribute to the sometimes high deviations between chronological age and epigenetic age predictions. In fact, the impact of such exogenous and endogenous parameters needs to be explored regarding each specific forensic application, for each choice of relevant age-associated $\mathrm{CpGs}$ that are considered for age-predictions, and for each method that is utilized for DNA methylation measurement.

Future research has to address also the risk of confounding biological factors and should focus on (1) the identification of forensically relevant biological/environmental confounding factors and (2) on the development of models that are "robust" against the influence of such biological factors.

\section{Identification of forensically relevant biological confounding factors}

Facing a growing list of factors influencing DNA methylation, the identification of relevant factors in the forensic context (estimation of chronological age) is of great importance. A factor is relevant, if it may cause significant and systematic deviations of epigenetic age estimates from chronological age and if it is likely to be present in forensic cases.

A first step towards the identification of relevant factors can be a pre-selection by analysis of published literature including clinical and basic science data, as done in this review. Taking into account the data in Tables 1 and 2, such preselected factors could be - for example-CMV infections (differences between epigenetic and chronological ages of 5 years, high incidences especially of $C M V$ infections).

In a second step, the influence of these factors on the quality of age estimation by models used for forensic age predictions can be tested by a targeted investigation of populations bearing possible confounding factors - a strategy that has already been chosen by Spolnicka et al. to test the relevance of physical activity and selected diseases [10-12].

However, some confounding factors may be interrelated (e.g. BMI, nutrition, low fitness and low socioeconomic status) and the individual impact of each of these interrelated factors can possibly not be differentiated clearly, since an independent investigation of them appears difficult.

The identification of forensically relevant factors, however, does not solve the question of how one can recognize if such a factor has to be taken into account in the individual forensic case. This problem arises especially in postmortem cases (unidentified deceased) and the analysis of blood traces of unknown donors for crime scene investigations. Spolnicka et al. [12] proposed a classification model for the identification of patients with chronic lymphocytic leukaemia (which has a strong impact on DNA methylation), deduced from the DNA methylation data. In living individuals, age estimation should consider the detailed medical history; specific questions should be asked about possible factors of influence.

\section{Development of models that are "robust" against the influence of confounding biological factors}

Models that are as robust against the influence of confounding biological factors as possible have to be developed to minimize the influences of the identified confounding factors on the quality of forensic age estimation.

Theoretically, models that include large numbers of CpGs could have the advantage that the influence of confounding biological factors on some markers may be "compensated" by an unaffected DNA methylation of other CpGs. However, even "large clocks" may be influenced by confounding biological factors (see "Horvath clock" (353 CpGs) and 
"Hannum clock" (71 CpGs) in Tables 1 and 2). The same is true for epigenetic models composed of a small number of CpGs, as shown for example by Spolnicka et al. [10] (5 CpGs). Within such models, some DNA methylation markers may be more sensitive towards confounding biological factors than others may, as shown for example for ELOVL2 and Clorf132 in three disease groups [11]. Focusing on a selected number of such "robust" CpGs in targeted assays may be a promising approach for the development of "robust" models for epigenetic age estimation; such "specialized" clocks [13, 80] may be much more powerful for forensic age estimation. This approach will result in models composed on only few CpGs, which will also be applicable in settings with low amounts of DNA of good quality. Another approach may be the consideration of identified confounding factors as parameters in prediction models.

The aim of optimization of epigenetic age estimation poses many challenges. Apart from aspects like the quality of DNA, applicability and suitability of methods, predictive markers, and integration of DNA methylation measurements into predictive models [80], it is important to elucidate how biological confounding factors affect epigenetic age-predictions. This interplay needs to be understood for reliable applications in forensic contexts. Collaborative research with coordinated research strategies is required to address this multitude of open research questions and to improve epigenetic methods for the estimation of chronological age.

Acknowledgements Open Access funding provided by Projekt DEAL.

Author contributions SR-T provided the idea for this review; BEK performed the gross literature search; BEK and SR-T drafted the manuscript; all authors participated in the evaluation of the cited studies as well as in the further elaboration and approved the final version.

Funding information This work was funded by Deutsche Forschungsgesellschaft (DFG), Project HEBE - "Human Epigenetics and Bioinformatics for Forensic Age Estimation” (RI 704/4-1, WA 1706/8-1).

\section{Compliance with ethical standards}

Conflict of interest WW is cofounder of Cygenia GmbH (www. cygenia.com), which can provide service for other scientists for epigenetic age predictions. YH contributes to this company, too.

Open Access This article is licensed under a Creative Commons Attribution 4.0 International License, which permits use, sharing, adaptation, distribution and reproduction in any medium or format, as long as you give appropriate credit to the original author(s) and the source, provide a link to the Creative Commons licence, and indicate if changes were made. The images or other third party material in this article are included in the article's Creative Commons licence, unless indicated otherwise in a credit line to the material. If material is not included in the article's Creative Commons licence and your intended use is not permitted by statutory regulation or exceeds the permitted use, you will need to obtain permission directly from the copyright holder. To view a copy of this licence, visit http://creativecommons.org/licenses/by/4.0/.

\section{References}

1. Ritz-Timme S, Cattaneo C, Collins MJ, Waite ER, Schutz HW, Kaatsch HJ, Borrman HI (2000) Age estimation: the state of the art in relation to the specific demands of forensic practise. Int $\mathbf{J}$ Legal Med 113(3):129-136

2. Horvath S (2013) DNA methylation age of human tissues and cell types. Genome Biol 14(10):R115. https://doi.org/10.1186/gb-201314-10-r115

3. Hannum G, Guinney J, Zhao L, Zhang L, Hughes G, Sadda S, Klotzle B, Bibikova M, Fan JB, Gao Y, Deconde R, Chen M, Rajapakse I, Friend S, Ideker T, Zhang K (2013) Genome-wide methylation profiles reveal quantitative views of human aging rates. Mol Cell 49(2):359-367. https://doi.org/10.1016/j.molcel.2012.10. 016

4. Levine ME, Lu AT, Quach A, Chen BH, Assimes TL, Bandinelli S, Hou L, Baccarelli AA, Stewart JD, Li Y, Whitsel EA, Wilson JG, Reiner AP, Aviv A, Lohman K, Liu Y, Ferrucci L, Horvath S (2018) An epigenetic biomarker of aging for lifespan and healthspan. Aging (Albany NY) 10(4):573-591. https://doi.org/ 10.18632/aging.101414

5. Weidner CI, Lin Q, Koch CM, Eisele L, Beier F, Ziegler P, Bauerschlag DO, Jockel KH, Erbel R, Muhleisen TW, Zenke M, Brummendorf TH, Wagner W (2014) Aging of blood can be tracked by DNA methylation changes at just three CpG sites. Genome Biol 15(2):R24. https://doi.org/10.1186/gb-2014-15-2-r24

6. Parson W (2018) Age estimation with DNA: from forensic DNA fingerprinting to forensic (epi)genomics: a mini-review. Gerontology. 64:326-332. https://doi.org/10.1159/000486239

7. Koop BE, Mayer F, Gündüz T, Blum J, Becker J, Schaffrath J, Wagner W, Han Y, Boehme P, Ritz-Timme S (2020) Postmortem age estimation via DNA methylation analysis in buccal swabs from corpses in different stages of decomposition - a "proof of principle" study. Int J Legal Med (in press)

8. Han Y, Franzen J, Stiehl T, Gobs M, Kuo CC, Nikolic M, Hapala J, Koop BE, Strathmann K, Ritz-Timme S, Wagner W (2020) New targeted approaches for epigenetic age predictions. BMC Biol 18(1):71. https://doi.org/10.1186/s12915-020-00807-2

9. Cho S, Jung SE, Hong SR, Lee EH, Lee JH, Lee SD, Lee HY (2017) Independent validation of DNA-based approaches for age prediction in blood. Forensic Sci Int Genet 29:250-256. https://doi. org/10.1016/j.fsigen.2017.04.020

10. Spolnicka M, Pospiech E, Adamczyk JG, Freire-Aradas A, Peplonska B, Zbiec-Piekarska R, Makowska Z, Pieta A, Lareu MV, Phillips C, Ploski R, Zekanowski C, Branicki W (2018) Modified aging of elite athletes revealed by analysis of epigenetic age markers. Aging (Albany NY) 10(2):241-252. https://doi.org/ 10.18632/aging.101385

11. Spolnicka M, Pospiech E, Peplonska B, Zbiec-Piekarska R, Makowska Z, Pieta A, Karlowska-Pik J, Ziemkiewicz B, Wezyk M, Gasperowicz P, Bednarczuk T, Barcikowska M, Zekanowski C, Ploski R, Branicki W (2017) DNA methylation in ELOVL2 and C1orf1 32 correctly predicted chronological age of individuals from three disease groups. Int J Legal Med 132:1-11. https://doi.org/10. 1007/s00414-017-1636-0

12. Spolnicka M, Zbiec-Piekarska R, Karp M, Machnicki MM, Wlasiuk P, Makowska Z, Pieta A, Gambin T, Gasperowicz P, Branicki W, Giannopoulos K, Stoklosa T, Ploski R (2018) DNA methylation signature in blood does not predict calendar age in patients with chronic lymphocytic leukemia but may alert to the presence of disease. Forensic Sci Int Genet 34:e15-e17. https://doi. org/10.1016/j.fsigen.2018.02.004

13. Bell CG, Lowe R, Adams PD, Baccarelli AA, Beck S, Bell JT, Christensen BC, Gladyshev VN, Heijmans BT, Horvath S, Ideker T, Issa JJ, Kelsey KT, Marioni RE, Reik W, Relton CL, Schalkwyk 
LC, Teschendorff AE, Wagner W, Zhang K, Rakyan VK (2019) DNA methylation aging clocks: challenges and recommendations. Genome Biol 20(1):249. https://doi.org/10.1186/s13059-019-1824$\mathrm{y}$

14. Zannas AS, Arloth J, Carrillo-Roa T, Iurato S, Roh S, Ressler KJ, Nemeroff CB, Smith AK, Bradley B, Heim C, Menke A, Lange JF, Bruckl T, Ising M, Wray NR, Erhardt A, Binder EB, Mehta D (2015) Lifetime stress accelerates epigenetic aging in an urban, African American cohort: relevance of glucocorticoid signaling. Genome Biol 16:266. https://doi.org/10.1186/s13059-015-0828-5

15. Boks MP, van Mierlo HC, Rutten BP, Radstake TR, De Witte L, Geuze E, Horvath S, Schalkwyk LC, Vinkers CH, Broen JC, Vermetten E (2015) Longitudinal changes of telomere length and epigenetic age related to traumatic stress and post-traumatic stress disorder. Psychoneuroendocrinology 51:506-512. https://doi.org/ 10.1016/j.psyneuen.2014.07.011

16. Wolf EJ, Logue MW, Hayes JP, Sadeh N, Schichman SA, Stone A, Salat DH, Milberg W, McGlinchey R, Miller MW (2016) Accelerated DNA methylation age: associations with PTSD and neural integrity. Psychoneuroendocrinology 63:155-162. https:// doi.org/10.1016/j.psyneuen.2015.09.020

17. Wolf EJ, Logue MW, Stoop TB, Schichman SA, Stone A, Sadeh N, Hayes JP, Miller MW (2017) Accelerated DNA methylation age: associations with PTSD and mortality. Psychosom Med 80:42-48. https://doi.org/10.1097/PSY.0000000000000506

18. Wolf EJ, Morrison FG (2017) Traumatic stress and accelerated cellular aging: from epigenetics to cardiometabolic disease. Curr Psychiatry Rep 19(10):75. https://doi.org/10.1007/s11920-0170823-5

19. Mehta D, Bruenig D, Lawford B, Harvey W, Carrillo-Roa T, Morris CP, Jovanovic T, Young RM, Binder EB, Voisey J (2018) Accelerated DNA methylation aging and increased resilience in veterans: the biological cost for soldiering on. Neurobiol Stress 8: 112-119. https://doi.org/10.1016/j.ynstr.2018.04.001

20. Wolf EJ, Maniates H, Nugent N, Maihofer AX, Armstrong D, Ratanatharathorn A, Ashley-Koch AE, Garrett M, Kimbrel NA, Lori A, Va Mid-Atlantic Mirecc W, Aiello AE, Baker DG, Beckham JC, Boks MP, Galea S, Geuze E, Hauser MA, Kessler RC, Koenen KC, Miller MW, Ressler KJ, Risbrough V, Rutten BPF, Stein MB, Ursano RJ, Vermetten E, Vinkers CH, Uddin M, Smith AK, Nievergelt CM, Logue MW (2018) Traumatic stress and accelerated DNA methylation age: a meta-analysis. Psychoneuroendocrinology 92:123-134. https://doi.org/10.1016/j. psyneuen.2017.12.007

21. Chen E, Miller GE, Yu T, Brody GH (2016) The great recession and health risks in African American youth. Brain Behav Immun 53:234-241. https://doi.org/10.1016/j.bbi.2015.12.015

22. Simons RL, Lei MK, Beach SR, Philibert RA, Cutrona CE, Gibbons FX, Barr A (2016) Economic hardship and biological weathering: the epigenetics of aging in a U.S. sample of black women. Soc Sci Med 150:192-200. https://doi.org/10.1016/j. socscimed.2015.12.001

23. Fiorito G, Polidoro S, Dugue PA, Kivimaki M, Ponzi E, Matullo G, Guarrera S, Assumma MB, Georgiadis P, Kyrtopoulos SA, Krogh V, Palli D, Panico S, Sacerdote C, Tumino R, Chadeau-Hyam M, Stringhini S, Severi G, Hodge AM, Giles GG, Marioni R, Karlsson Linner R, O'Halloran AM, Kenny RA, Layte R, Baglietto L, Robinson O, McCrory C, Milne RL, Vineis P (2017) Social adversity and epigenetic aging: a multi-cohort study on socioeconomic differences in peripheral blood DNA methylation. Sci Rep 7(1): 16266. https://doi.org/10.1038/s41598-017-16391-5

24. Jovanovic T, Vance LA, Cross D, Knight AK, Kilaru V, Michopoulos V, Klengel T, Smith AK (2017) Exposure to violence accelerates epigenetic aging in children. Sci Rep 7(1):8962. https:// doi.org/10.1038/s41598-017-09235-9
25. Hughes A, Smart M, Gorrie-Stone T, Hannon E, Mill J, Bao Y, Burrage J, Schalkwyk L, Kumari M (2018) Socioeconomic position and DNA methylation age acceleration across the Lifecourse. Am J Epidemiol 187:2346-2354. https://doi.org/10.1093/aje/kwy155

26. Austin MK, Chen E, Ross KM, McEwen LM, Maclsaac JL, Kobor MS, Miller GE (2018) Early-life socioeconomic disadvantage, not current, predicts accelerated epigenetic aging of monocytes. Psychoneuroendocrinology 97:131-134. https://doi.org/10.1016/j. psyneuen.2018.07.007

27. Fiorito G, McCrory C, Robinson O, Carmeli C, Rosales CO, Zhang Y, Colicino E, Dugue PA, Artaud F, McKay GJ, Jeong A, Mishra PP, Nost TH, Krogh V, Panico S, Sacerdote C, Tumino R, Palli D, Matullo G, Guarrera S, Gandini M, Bochud M, Dermitzakis E, Muka T, Schwartz J, Vokonas PS, Just A, Hodge AM, Giles GG, Southey MC, Hurme MA, Young I, McKnight AJ, Kunze S, Waldenberger M, Peters A, Schwettmann L, Lund E, Baccarelli A, Milne RL, Kenny RA, Elbaz A, Brenner H, Kee F, Voortman T, Probst-Hensch N, Lehtimaki T, Elliot P, Stringhini S, Vineis P, Polidoro S, Consortium B, Lifepath C (2019) Socioeconomic position, lifestyle habits and biomarkers of epigenetic aging: a multicohort analysis. Aging (Albany NY) 11(7):2045-2070. https://doi. org/10.18632/aging. 101900

28. Tajuddin SM, Hernandez DG, Chen BH, Noren Hooten N, Mode NA, Nalls MA, Singleton AB, Ejiogu N, Chitrala KN, Zonderman AB, Evans MK (2019) Novel age-associated DNA methylation changes and epigenetic age acceleration in middle-aged African Americans and whites. Clin Epigenetics 11(1):119. https://doi.org/ 10.1186/s13148-019-0722-1

29. Thurston RC, Carroll JE, Levine M, Chang Y, Crandall C, Manson JE, Pal L, Hou L, Shadyab AH, Horvath S (2020) Vasomotor symptoms and accelerated epigenetic aging in the Women's Health Initiative (WHI). J Clin Endocrinol Metab 105(4):12211227. https://doi.org/10.1210/clinem/dgaa081

30. Marini S, Davis KA, Soare TW, Zhu Y, Suderman MJ, Simpkin AJ, Smith A, Wolf EJ, Relton CL, Dunn EC (2020) Adversity exposure during sensitive periods predicts accelerated epigenetic aging in children. Psychoneuroendocrinology 113:104484. https:// doi.org/10.1016/j.psyneuen.2019.104484

31. Linner RK, Marioni RE, Rietveld CA, Simpkin AJ, Davies NM, Watanabe K, Armstrong NJ, Auro K, Baumbach C, Bonder MJ, Buchwald J, Fiorito G, Ismail K, Iurato S, Joensuu A, Karell P, Kasela S, Lahti J, Mcrae AF, Mandaviya PR, Seppala I, Wang Y, Baglietto L, Binder EB, Harris SE, Hodge AM, Horvath S, Hurme M, Johannesson M, Latvala A, Mather KA, Medland SE, Metspalu A, Milani L, Milne RL, Pattie A, Pedersen NL, Peters A, Polidoro S, Raikkonen K, Severi G, Starr JM, Stolk L, Waldenberger M, Eriksson JG, Esko T, Franke L, Gieger C, Giles GG, Hagg S, Jousilahti P, Kaprio J, Kahonen M, Lehtimaki T, Martin NG, van Meurs JBC, Ollikainen M, Perola M, Posthuma D, Raitakari OT, Sachdev PS, Taskesen E, Uitterlinden AG, Vineis P, Wijmenga C, Wright MJ, Relton C, Smith GD, Deary IJ, Koellinger PD, Benjamin DJ, Consortium B (2017) An epigenome-wide association study meta-analysis of educational attainment. Mol Psychiatry 22(12):1680-1690. https://doi.org/10.1038/mp.2017.210

32. McCartney DL, Stevenson AJ, Walker RM, Gibson J, Morris SW, Campbell A, Murray AD, Whalley HC, Porteous DJ, McIntosh AM, Evans KL, Deary IJ, Marioni RE (2018) Investigating the relationship between DNA methylation age acceleration and risk factors for Alzheimer's disease. Alzheimers Dement (Amst) 10: 429-437. https://doi.org/10.1016/j.dadm.2018.05.006

33. Quach A, Levine ME, Tanaka T, Lu AT, Chen BH, Ferrucci L, Ritz B, Bandinelli S, Neuhouser ML, Beasley JM, Snetselaar L, Wallace RB, Tsao PS, Absher D, Assimes TL, Stewart JD, Li Y, Hou L, Baccarelli AA, Whitsel EA, Horvath S (2017) Epigenetic clock analysis of diet, exercise, education, and lifestyle factors. Aging 
(Albany NY) 9(2):419-446. https://doi.org/10.18632/aging. 101168

34. Sumner JA, Colich NL, Uddin M, Armstrong D, McLaughlin KA (2018) Early experiences of threat, but not deprivation, are associated with accelerated biological aging in children and adolescents. Biol Psychiatry 85:268-278. https://doi.org/10.1016/j.biopsych. 2018.09.008

35. Brody GH, Miller GE, Yu T, Beach SR, Chen E (2016) Supportive family environments ameliorate the link between racial discrimination and epigenetic aging: a replication across two longitudinal cohorts. Psychol Sci 27(4):530-541. https://doi.org/10.1177/ 0956797615626703

36. Dugue PA, Bassett JK, Joo JE, Jung CH, Ming Wong E, MorenoBetancur M, Schmidt D, Makalic E, Li S, Severi G, Hodge AM, Buchanan DD, English DR, Hopper JL, Southey MC, Giles GG, Milne RL (2018) DNA methylation-based biological aging and cancer risk and survival: pooled analysis of seven prospective studies. Int J Cancer 142(8):1611-1619. https://doi.org/10.1002/ijc. 31189

37. Perna L, Zhang Y, Mons U, Holleczek B, Saum KU, Brenner H (2016) Epigenetic age acceleration predicts cancer, cardiovascular, and all-cause mortality in a German case cohort. Clin Epigenetics 8: 64. https://doi.org/10.1186/s13148-016-0228-Z

38. Zheng Y, Joyce BT, Colicino E, Liu L, Zhang W, Dai Q, Shrubsole MJ, Kibbe WA, Gao T, Zhang Z, Jafari N, Vokonas P, Schwartz J, Baccarelli AA, Hou L (2016) Blood epigenetic age may predict cancer incidence and mortality. EBioMedicine 5:68-73. https:// doi.org/10.1016/j.ebiom.2016.02.008

39. Ambatipudi S, Horvath S, Perrier F, Cuenin C, Hernandez-Vargas H, Le Calvez-Kelm F, Durand G, Byrnes G, Ferrari P, Bouaoun L, Sklias A, Chajes V, Overvad K, Severi G, Baglietto L, ClavelChapelon F, Kaaks R, Barrdahl M, Boeing H, Trichopoulou A, Lagiou P, Naska A, Masala G, Agnoli C, Polidoro S, Tumino R, Panico S, Dolle M, Peeters PHM, Onland-Moret NC, Sandanger TM, Nost TH, Weiderpass E, Quiros JR, Agudo A, RodriguezBarranco M, Huerta Castano JM, Barricarte A, Fernandez AM, Travis RC, Vineis P, Muller DC, Riboli E, Gunter M, Romieu I, Herceg Z (2017) DNA methylome analysis identifies accelerated epigenetic ageing associated with postmenopausal breast cancer susceptibility. Eur J Cancer 75:299-307. https://doi.org/10.1016/j. ejca.2017.01.014

40. Levine ME, Hosgood HD, Chen B, Absher D, Assimes T, Horvath S (2015) DNA methylation age of blood predicts future onset of lung cancer in the women's health initiative. Aging (Albany NY) 7(9):690-700. https://doi.org/10.18632/aging.100809

41. Durso DF, Bacalini MG, Sala C, Pirazzini C, Marasco E, Bonafe M, do Valle IF, Gentilini D, Castellani G, Faria AMC, Franceschi C, Garagnani P, Nardini C (2017) Acceleration of leukocytes' epigenetic age as an early tumor and sex-specific marker of breast and colorectal cancer. Oncotarget 8(14):23237-23245. https://doi.org/ 10.18632/oncotarget.15573

42. Nevalainen T, Kananen L, Marttila S, Jylhava J, Mononen N, Kahonen M, Raitakari OT, Hervonen A, Jylha M, Lehtimaki T, Hurme M (2017) Obesity accelerates epigenetic aging in middleaged but not in elderly individuals. Clin Epigenetics 9:20. https:// doi.org/10.1186/s13148-016-0301-7

43. Simpkin AJ, Cooper R, Howe LD, Relton CL, Davey Smith G, Teschendorff A, Widschwendter M, Wong A, Kuh D, Hardy R (2017) Are objective measures of physical capability related to accelerated epigenetic age? Findings from a British birth cohort. BMJ Open 7(10):e016708. https://doi.org/10.1136/bmjopen-2017016708

44. Li C, Wang Z, Hardy T, Huang Y, Hui Q, Crusto CA, Wright ML, Taylor JY, Sun YV (2019) Association of Obesity with DNA methylation age acceleration in African American mothers from the
InterGEN study. Int J Mol Sci 20(17). https://doi.org/10.3390/ ijms 20174273

45. Horvath S, Levine AJ (2015) HIV-1 infection accelerates age according to the epigenetic clock. J Infect Dis 212(10):1563-1573. https://doi.org/10.1093/infdis/jiv277

46. Gross AM, Jaeger PA, Kreisberg JF, Licon K, Jepsen KL, Khosroheidari M, Morsey BM, Swindells S, Shen H, Ng CT, Flagg K, Chen D, Zhang K, Fox HS, Ideker T (2016) Methylome-wide analysis of chronic HIV infection reveals fiveyear increase in biological age and epigenetic targeting of HLA. Mol Cell 62(2):157-168. https://doi.org/10.1016/j.molcel.2016.03. 019

47. Kananen L, Nevalainen T, Jylhava J, Marttila S, Hervonen A, Jylha M, Hurme M (2015) Cytomegalovirus infection accelerates epigenetic aging. Exp Gerontol 72:227-229. https://doi.org/10.1016/j. exger.2015.10.008

48. Gao X, Zhang Y, Brenner H (2017) Associations of helicobacter pylori infection and chronic atrophic gastritis with accelerated epigenetic ageing in older adults. Br J Cancer 117(8):1211-1214. https://doi.org/10.1038/bjc.2017.314

49. Rosen AD, Robertson KD, Hlady RA, Muench C, Lee J, Philibert R, Horvath S, Kaminsky ZA, Lohoff FW (2018) DNA methylation age is accelerated in alcohol dependence. Transl Psychiatry 8(1): 182. https://doi.org/10.1038/s41398-018-0233-4

50. Luo A, Jung J, Longley M, Rosoff DB, Charlet K, Muench C, Lee J, Hodgkinson CA, Goldman D, Horvath S, Kaminsky ZA, Lohoff FW (2020) Epigenetic aging is accelerated in alcohol use disorder and regulated by genetic variation in APOL 2 . Neuropsychopharmacology 45(2):327-336. https://doi.org/10. 1038/s41386-019-0500-y

51. Gao X, Zhang Y, Breitling LP, Brenner H (2016) Relationship of tobacco smoking and smoking-related DNA methylation with epigenetic age acceleration. Oncotarget 7(30):46878-46889. https:// doi.org/10.18632/oncotarget.9795

52. Vidal-Bralo L, Lopez-Golan Y, Gonzalez A (2016) Simplified assay for epigenetic age estimation in whole blood of adults. Front Genet 7:126. https://doi.org/10.3389/fgene.2016.00126

53. Yang Y, Gao X, Just AC, Colicino E, Wang C, Coull BA, Hou L, Zheng Y, Vokonas P, Schwartz J, Baccarelli AA (2019) Smokingrelated DNA methylation is associated with DNA methylation phenotypic age acceleration: the veterans affairs normative aging study. Int J Environ Res Public Health 16(13). https://doi.org/10.3390/ ijerph16132356

54. Ward-Caviness CK, Nwanaji-Enwerem JC, Wolf K, Wahl S, Colicino E, Trevisi L, Kloog I, Just AC, Vokonas P, Cyrys J, Gieger C, Schwartz J, Baccarelli AA, Schneider A, Peters A (2016) Long-term exposure to air pollution is associated with biological aging. Oncotarget 7(46):74510-74525. https://doi.org/10. 18632/oncotarget.12903

55. Li J, Zhu X, Yu K, Jiang H, Zhang Y, Wang B, Liu X, Deng S, Hu J, Deng Q, Sun H, Guo H, Zhang X, Chen W, Yuan J, He M, Bai Y, Han X, Liu B, Liu C, Guo Y, Zhang B, Zhang Z, Hu FB, Gao W, Li L, Lathrop M, Laprise C, Liang L, Wu T (2018) Exposure to polycyclic aromatic hydrocarbons and accelerated DNA methylation aging. Environ Health Perspect 126(6):067005. https://doi.org/10. 1289/EHP2773

56. Nwanaji-Enwerem JC, Colicino E, Trevisi L, Kloog I, Just AC, Shen J, Brennan K, Dereix A, Hou L, Vokonas P, Schwartz J, Baccarelli AA (2016) Long-term ambient particle exposures and blood DNA methylation age: findings from the VA normative aging study. Environ Epigenet 2(2). https://doi.org/10.1093/eep/ dvw006

57. Nwanaji-Enwerem JC, Dai L, Colicino E, Oulhote Y, Di Q, Kloog I, Just AC, Hou L, Vokonas P, Baccarelli AA, Weisskopf MG, Schwartz JD (2017) Associations between long-term exposure to PM2.5 component species and blood DNA methylation age in the 
elderly: the VA normative aging study. Environ Int 102:57-65. https://doi.org/10.1016/j.envint.2016.12.024

58. Lind PM, Salihovic S, Lind L (2018) High plasma organochlorine pesticide levels are related to increased biological age as calculated by DNA methylation analysis. Environ Int 113:109-113. https:// doi.org/10.1016/j.envint.2018.01.019

59. White AJ, Kresovich JK, Keller JP, Xu Z, Kaufman JD, Weinberg CR, Taylor JA, Sandler DP (2019) Air pollution, particulate matter composition and methylation-based biologic age. Environ Int 132: 105071. https://doi.org/10.1016/j.envint.2019.105071

60. Horvath S, Gurven M, Levine ME, Trumble BC, Kaplan H, Allayee H, Ritz BR, Chen B, Lu AT, Rickabaugh TM, Jamieson BD, Sun D, Li S, Chen W, Quintana-Murci L, Fagny M, Kobor MS, Tsao PS, Reiner AP, Edlefsen KL, Absher D, Assimes TL (2016) An epigenetic clock analysis of race/ethnicity, sex, and coronary heart disease. Genome Biol 17(1):171. https://doi.org/10. 1186/s13059-016-1030-0

61. Simpkin AJ, Hemani G, Suderman M, Gaunt TR, Lyttleton O, McArdle WL, Ring SM, Sharp GC, Tilling K, Horvath S, Kunze S, Peters A, Waldenberger M, Ward-Caviness C, Nohr EA, Sorensen TI, Relton CL, Smith GD (2016) Prenatal and early life influences on epigenetic age in children: a study of motheroffspring pairs from two cohort studies. Hum Mol Genet 25(1): 191-201. https://doi.org/10.1093/hmg/ddv456

62. Javed R, Chen W, Lin F, Liang H (2016) Infant's DNA methylation age at birth and epigenetic aging accelerators. Biomed Res Int 2016: 4515928-4515910. https://doi.org/10.1155/2016/4515928

63. Zbiec-Piekarska R, Spolnicka M, Kupiec T, Parys-Proszek A, Makowska Z, Paleczka A, Kucharczyk K, Ploski R, Branicki W (2015) Development of a forensically useful age prediction method based on DNA methylation analysis. Forensic Sci Int Genet 17: 173-179. https://doi.org/10.1016/j.fsigen.2015.05.001

64. Carroll JE, Irwin MR, Levine M, Seeman TE, Absher D, Assimes T, Horvath S (2017) Epigenetic aging and immune senescence in women with insomnia symptoms: findings from the Women's Health Initiative study. Biol Psychiatry 81(2):136-144. https://doi. org/10.1016/j.biopsych.2016.07.008

65. White AJ, Kresovich JK, Xu Z, Sandler DP, Taylor JA (2019) Shift work, DNA methylation and epigenetic age. Int J Epidemiol 48: 1536-1544. https://doi.org/10.1093/ije/dyz027

66. Brody GH, Yu T, Chen E, Beach SR, Miller GE (2016) Familycentered prevention ameliorates the longitudinal association between risky family processes and epigenetic aging. J Child Psychol Psychiatry 57(5):566-574. https://doi.org/10.1111/jcpp. 12495

67. Horvath S, Ritz BR (2015) Increased epigenetic age and granulocyte counts in the blood of Parkinson's disease patients. Aging (Albany NY) 7(12):1130-1142. https://doi.org/10.18632/aging. 100859

68. Horvath S, Oshima J, Martin GM, Lu AT, Quach A, Cohen H, Felton S, Matsuyama M, Lowe D, Kabacik S, Wilson JG, Reiner AP, Maierhofer A, Flunkert J, Aviv A, Hou L, Baccarelli AA, Li Y, Stewart JD, Whitsel EA, Ferrucci L, Matsuyama S, Raj K (2018) Epigenetic clock for skin and blood cells applied to Hutchinson Gilford Progeria syndrome and ex vivo studies. Aging (Albany NY) 10(7):1758-1775. https://doi.org/10.18632/aging.101508

69. Martin-Herranz DE, Aref-Eshghi E, Bonder MJ, Stubbs TM, Choufani S, Weksberg R, Stegle O, Sadikovic B, Reik W,
Thornton JM (2019) Screening for genes that accelerate the epigenetic aging clock in humans reveals a role for the H3K36 methyltransferase NSD1. Genome Biol 20(1). https://doi.org/10.1186/ s13059-019-1753-9

70. Horvath S, Pirazzini C, Bacalini MG, Gentilini D, Di Blasio AM, Delledonne M, Mari D, Arosio B, Monti D, Passarino G, De Rango F, D'Aquila P, Giuliani C, Marasco E, Collino S, Descombes P, Garagnani P, Franceschi C (2015) Decreased epigenetic age of PBMCs from Italian semi-supercentenarians and their offspring. Aging (Albany NY) 7(12):1159-1170. https://doi.org/10.18632/ aging. 100861

71. Kresovich JK, Harmon QE, Xu Z, Nichols HB, Sandler DP, Taylor JA (2019) Reproduction, DNA methylation and biological age. Hum Reprod 34(10):1965-1973. https://doi.org/10.1093/humrep/ dez149

72. Stringhini S, Sabia S, Shipley M, Brunner E, Nabi H, Kivimaki M, Singh-Manoux A (2010) Association of socioeconomic position with health behaviors and mortality. JAMA 303(12):1159-1166. https://doi.org/10.1001/jama.2010.297

73. Geronimus AT, Hicken M, Keene D, Bound J (2006) "Weathering" and age patterns of allostatic load scores among blacks and whites in the United States. Am J Public Health 96(5):826-833. https://doi. org/10.2105/AJPH.2004.060749

74. Abbott A (2018) European scientists seek 'epigenetic clock' to determine age of refugees. Nature 561(7721):15. https://doi.org/ 10.1038/d41586-018-06121-w

75. Eipel M, Bozic T, Mies A, Beier F, Jost E, Brummendorf TH, Platzbecker U, Wagner W (2019) Tracking myeloid malignancies by targeted analysis of successive DNA methylation at neighboring CG dinucleotides. Haematologica 104(8):e349-e351. https://doi. org/10.3324/haematol.2018.209734

76. Lin Q, Wagner W (2015) Epigenetic aging signatures are coherently modified in cancer. PLoS Genet 11(6):e1005334. https://doi.org/ 10.1371/journal.pgen.1005334

77. Adland E, Klenerman P, Goulder P, Matthews PC (2015) Ongoing burden of disease and mortality from HIV/CMV coinfection in Africa in the antiretroviral therapy era. Front Microbiol 6:1016. https://doi.org/10.3389/fmicb.2015.01016

78. Gao X, Jia M, Zhang Y, Breitling LP, Brenner H (2015) DNA methylation changes of whole blood cells in response to active smoking exposure in adults: a systematic review of DNA methylation studies. Clin Epigenetics 7:113. https://doi.org/10.1186/ s13148-015-0148-3

79. Sillanpaa E, Ollikainen M, Kaprio J, Wang X, Leskinen T, Kujala UM, Tormakangas T (2019) Leisure-time physical activity and DNA methylation age-a twin study. Clin Epigenetics 11(1):12. https://doi.org/10.1186/s13148-019-0613-5

80. Han Y, Franzen J, Stiehl T, Gobs M, Chao-Chung Kuo J, Nikolić M, Hapala J, Koop B, Strathmann K, Ritz-Timme S, Wagner W (2020) New targeted approaches for epigenetic age predictions. BMC Biology (in press):https://www.biorxiv.org/content/10.1101/ 799031v799031.full

Publisher's note Springer Nature remains neutral with regard to jurisdictional claims in published maps and institutional affiliations. 